\title{
Khillafah dan Negara-Bangsa: Pertarungan Legitimasi yang belum Usai
}

\section{A. Aziz}

\section{Abstract}

Negara Khilafah, hingga hari ini sejatinya masih ada, tidak ikut lenyap bersamaan dengan penghapusan Kesultanan Turki Usmani pada 1924 M. Negara Khilafah itu adalah Marokko (Al-Maghrib al-Aqsha) di Afrika Utara, sebagai kelanjutan dari Dinasti Sa'di-Alawi yang dirintis di kota Sus pada 1510 M, oleh Abu Abdillah al-Qa im bi Amrillah (w. 1517 M.). Persaingan memperebutkan supremasi sebagai negara Khilafah terjadi antara Dinasti Sa'di Alawi dengan Dinasti Turki-Usmani sejak abad ke-16. Baik secara teritorial maupun nonteroterial, Turki Usmani yang pada saat itu sangat besar dan kuat, tidak dapat dibandingkan dengan Dinasti Sa'diAlawi yang hanya menguasai Al-Maghrib al-Aqsha dan rentan terhadap pengaruh luar. Bahkan pada masa kejayaannya di bawah Ahmad Al-Manshur (w.1603 M.) dan Maulay Isma'il (w.1727 M.), ekspansi Dinasti Sa'di-Alawi hanya sampai Songhay (Mali) di selatan Sahara. Namun, Dinasti Sa'diAlawi ini mampu membangun identitas Khilafahnya sendiri yang khas. Dinasti ini tidak pernah mengaku tunduk kepada Khilafah Turki Usmani, kecuali pada masa yang singkat oleh pendahulu Al-Manshur, Abdul Malik (1576-1578 M.)
Keywords

khilafah; negara-bangsa; legitimasi

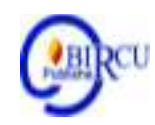

\section{Pendahuluan}

Kitab-kitab klasik standar Muslim Sunni seperti Al-Ahkam al-Sulthaniyyah karya A Mawardi (w.1058 M.), menyebut sejumlah kriteria imamah/khilafah. Misalnya, menegakkan imamah/khilafah adalah kewajiban kolektif (wajib kifayah) bagi muslim dan dilakukan melalui bay'ah (sumpah setia); Imam/Khalifah harus berasal dari kabilah Quraisy; tugas utama Imam/Khalifah ialah menjaga agama (Islam) dan mengelola urusan dunia; hanya ada satu Khilafah dan satu orang Imam/Khalifah di seluruh dunia Islam.2 Merujuk kepada kriteria Khilafah di atas, Dinasti Sa'di-Alawi di Marokko telah memenuhinya, termasuk kewajiban kolektif Muslim mennegakkannya. Hingga hari ini, gelar Amir al-Mukminin masih digunakan untuk menyebut Kepala Negara Marokko, sama seperti pada abad ke-16 yang lalu.3

Fenomena Marokko merupakan manifestasi dari suatu pertarungan legitimasi dan ketegangan konseptual ideologis yang masih sedang berlangsung di dunia Islam, antara gagasan negara universal Khilafah yang telah menjadi bagian integral dari peradaban Muslim, dengan gagasan negara teritorial negara-bangsa. Gagasan negara-bangsa terpaksa diadaptasi oleh para pengusung peradaban Muslim dari peradaban Euro-Amerika, sebagai kelanjutan dari kekalahan dan dominasi pembawa peradaban Euro-Amerika atas mereka.

Guna memperoleh pemetaan yang lebih luas mengenai skala pertarungan tersebut, bagian tulisan ini akan menyajikan contoh kasus dari enam negara berpenduduk mayoritas muslim, yaitu Marokko, Saudi Arabia, Mesir, Pakistan, Iran dan Indonesia. 


\section{Kajian Pustaka}

\subsection{Khilafah Syarifian Marokko}

Kehadiran Dinasti Sa'di pada awal abad ke-16, menandai perubahan basis politik di Marokko. Pada periode ini, elemen keturunan Quraisy (Syarif, jamak: Syurafa') dan tarekat sufi menjadi basis kekuasaan politik dan keagamaan, menggeser dominasi ekslusif elemen kesukuan seperti disandang oleh Dinasti Mariniyah (1244-1465 M.) dan Dinasti Watthasiyah (1472-1554 M.), keduanya dari suku Berber Zanata. Dinasti Sa'di membangun kekuasaanya dengan dukungan Tarekat Syadziliyah dari suku Berber Jazulah pimpinan Muhammad Al Jazuli (w.1465 M.), yang populer di kota Fez. Penerus Dinasti Sa'di, yakni Dinasti Alawi yang berkuasa pada akhir abad ke-17 hingga hari ini, juga diyakini sebagai kaum Syarif.

Kelahiran kota-kota baru dan pertumbuhan para pedagang maupun pengrajin yang menetap, memerlukan kepemimpinan baru yang dianggap mampu menyatukan mereka dalam mengatasi ancaman internal maupun eksternal, khususnya Portugis. Selama kekuasaan Watthasiyah yang hanya menguasai bagian utara Marokko, Portugis berhasil menguasai wilayah pesisir relatif luas, mulai dari kota Tangier di utara hingga ke kota Agadir di selatan.4 Keluarga Sa'di berhasil melakukan konsolidasi kekuasaan di seluruh Marokko di tangan anak Al-Qaim, Muhammad Al-Syaikh (w.1557 M.), setelah pada 1540 M. berhasil menumbangkan kekuasaan anak tertua Al-Qaim, Ahmad Al-A'raj (w.1544 M.) yang berpusat di kota Marrakesh. Berikutnya As-Syaikh merebut kota Agadir dari Portugis pada $1541 \mathrm{M}$. yang menandai kehancuran pengaruh negara itu di Marokko. Akhirnya Al-Syaikh mampu mengalahkan Dinasti Wattasiyah dan merebut kota Fez pada 1544 M. Rivalitas Khilafah terjadi antara Sa'di dengan Turki Usmani yang Sultannya disebut "Sultan Kaum Nelayan" oleh Al-Syaikh. Kesuksesannya menangkal kehadiran tentara Turki di Marokko, bahkan sempat menduduki kota Tlemcen sebagai perbatasan barat Turki Usmani, menyebabkan tokoh ini dibunuh oleh elemen Turki dalam pasukannya, atas restu penguasa Istanbul.

Sukses Muhammad Al-Syaikh melakukan konsolidasi kekuasaan Dinasti Sa'di atas seluruh Marokko, dilanjutkan oleh anak bungsunya Ahmad al-Manshur. Sebelum berkuasa pada 1578 M, Al-Manshur menyertai kakaknya Abd al-Malik (w.1578 M.) dalam perang saudara dengan anak sulung dan pelanjut Al-Syaikh, Abdullah al-Ghalib (w.1574 M.) dan anaknya, Al-Mutawakkil (w.1578 M.). Selama masa konsolidasi oleh Al-Manshur, Syarifisme, yakni suatu keyakinan bahwa kaum Syarif berhak memimpin dan berkemampuan mempersatukan penduduk kota maupun desa al-Maghrib al-Aqsha dan berjihad, tumbuh menjadi basis ideologis rakyat Marokko. Syarifisme masih terpelihara hingga hari ini dan menjadi bagian dari institusi yang disebut Makhzen. Ketika Al-Manshur wafat, Marokko terbelah dua dan mengalami perang saudara. Bagian utara berpusat di Fez, dikuasai oleh Muhammad al-Ma`mun (w.1608 M.) dan keturunannya. Sedangkan bagian selatan berada di bawah Abu Ma'ali Zaydan (w.1627 M.) dan keturunannya, berpusat di Marrakesh.

Konflik internal Dinasti Sa'di memicu pemisahan diri oleh sejumlah zawiyah (padepokan) tarekat, kabilah dan kaum Syarif dengan alasan Dinasti itu telah lemah dalam berjihad. Maka, dari oasis Tafilalt di selatan, muncul kaum Syarif dari keluarga Alawi. Kekuasaan mereka dirintis di kota Sijilmasa pada $1631 \mathrm{M}$. oleh Ali al-Syarif ben Youssef (w.1659 M.). Pada 1650 M, anak Al-Syarif bernama Muhammad beroleh dukungan dari kabilah-kabilah Arab di utara Marokko. Namun, ketika Al-Syarif wafat, dukungan itu dialihkan kepada Al-Rasyid, saudara Muhammad. Dalam upaya memerangi para mantan pendukungnya itulah, Muhammad bin Al-Syarif tewas pada 1664 M. Al-Rasyid segera menyatukan Marokko dengan merebut Fez pada 1666 M, dan Marrakesh pada 1668 M. Namun Al-Rasyid mendadak wafat pada 1872 M. dan kekuasaan beralih ke tangan adiknya, Maulay Isma'il, yang berkuasa selama 55 tahun hingga wafat pada 1727 M.7 


\subsection{Khilafah Sebagai Pilar Makhzen}

Kemampuan Dinasti Alawi mempertahankan kekuasaan hingga ke masa modern ini, tidak terlepas dari jasa besar dua penguasa Dinasti Syarifian, yaitu Ahmad al-Manshur dari Dinasti Sa'di dan Maulay Isma'il dari Dinasti Alawi. Keduanya telah menegakkan pilar-pilar sistem pemerintahan yang fleksibel dan khas bagi Marokko, yang melanggengkan Syarifisme dan Khilafah sebagai basis kekuasaan, melalui penguatan institusi dwi-tunggal Bled alMakhzen (area pemerintah) dan Bled al-Siba (area pembangkang). Tokoh yang berjasa menyeimbangkan dua intsitusi itu dalam praktik politik Dinasti Syarifian Marokko, ialah cucu Isma'il, Sidi Muhammad III yang berkuasa dari 1757 M, sampai 1790 M. Berkat jasanya, pola Makhzenit menjadi sistem pemerintahan yang fleksibel, stabil dan khas.8 Melalui dinamika politik abad-abad berikutnya, termasuk periode pendudukan Perancis selama sekitar setengah abad, sistem pemerintahan Makhzenit mampu bertahan hingga hari ini.

Levtzion menjelaskan,9 Bled al-Makhzen (Bilad al-Makhzan) adalah area/wilayah yang secara praktis dikontrol oleh pemerintah pusat dan di bawah pengaruh kota-kota, yang terintegrasi ke dalam jaringan sosial ekonomi Kesultanan/Khilafah. Sedangkan Bled al-Siba (Bilad al-Sibah) adalah area yang secara teoritis berada di luar kontrol pemerintah pusat, tetapi secara kultural mengakui otoritasnya. Tidak ada batas yang pasti di antara kedua area itu. Ketika penguasa kuat, maka batas Bled al-Makhzen dapat saja diperluasnya. Tetapi ketika penguasa lemah, maka sebaliknya, Bled al-Siba yang meluas. Akabouch10 merinci penggunaan konsep Makhzen yang mengandung makna lebih luas. Kata Makhzen berasal dari bahasa Arab, yang secara harfiah berarti "gudang" dan merujuk kepada pajak yang dipungut dan dikumpulkan pemerintah pusat dari suku-suku yang menyerah. Sebagai sebuah konsep, Makhzen berkaitan dengan pembangkangan sukusuku di Pengunungan Atlas, khususnya Atlas Tengah dan Atlas Tinggi, terhadap pemerintah pusat. Konsep itu pertama kali muncul dan digunakan oleh Dinasti Sa'di (1554 M. - 1659 M), guna merujuk kepada suatu sistem politik tradisional yang mereka bangun dalam kerangka rasionalisasi kekuasaan monarki mereka mempersatukan seluruh Marokko berdasarkan ikatan religius.

Menurut Daadaoui,11 konsep Makhzen telah bergeser dari makna harfiahnya sebagai kebendaharaan pemerintah, kepada interpretasi sosio-politis sebagai "gudang kekuasaan". Kekuasaan ini terdiri atas dua elemen utama, yaitu otoritas administrasi pemerintahan dan militer, di samping otoritas simbolik Sultan sebagai pemimpin kekuasaan keagamaan beserta seluruh perangkat seremonialnya. Struktur yang tercakup dalam elemen pertama adalah Sultan sebagai pemimpin umat dan inti kekuasaan, serta menteri-menteri dan birokrasi yang memberikan pelayanan atas nama negara. Dalam lingkup Bled al-Makhzen, struktur kekuasan di wilayah pedesaan adalah Ca`id, sebagai kepanjangan kekuasaan Sultan. Ca`id adalah tokoh lokal atau tetua suku pemilik lahan yang dalam melaksanakan tugasnya dibantu oleh Syeikh dan Muqaddem sesuai disposisi Ca'id. Di daerah perkotaan, terdapat struktur birokrasi seperti muhtasib sebagai penjaga moral dan transaksi ekonomi, khususnya pasar. Sedangkan dalam lingkup Bled al-Siba, struktur kekuasaan berada di tangan Jama'ah (Majelis Para Tokoh dan Tetua) yang mengatur suku-suku independen yang berada di luar jangkauan kekuasaan perpajakan Sultan, tetapi mengakui otoritas religiusnya.

Elemen pertama, yakni otoritas administrasi dan militer, beserta strukturnya yang fleksibel, ditambah dengan berbagai ritual dan perayaan resmi sebagai simbol keabsahan dan stabilitas monarki secara sosio-politis dan sosio-religius, merupakan aspek otoritas Makhzen yang kasat mata (hard power). Sedangkan elemen kedua, otoritas simbolik Sultan, adalah aspek otoritas Makhzen yang tidak tidak kasat mata (soft power) dan setidaknya mencakup empat sub-elemen. Keempatnya adalah Syarifisme; kepemimpinan religius Amir alMu`minin; Baraka yang memancar dari Sultan sebagai keturunan Rasul dan pemimpin 
Ummah; serta Bay'ah (sumpah setia). Sebagai Amir al-Mu`minin, Sultan adalah penjaga agama yang menghegemoni wacana keagamaan. Hegemoni ini diperkuat dengan Bay'ah yang dihasilkan melalui upacara tahunan pernyataan sumpah setia yang diikuti oleh ribuan pejabat tinggi, anggota kabinet, ulama, korps militer, anggota parlemen, kaum birokrat, serta para pemimpin lokal yang dipilih maupun yang diangkat. Mereka berbaris di depan

Sultan yang menunggang kuda dan membungkuk lima kali sebagai tanda sumpah setia. Seluruh sub-elemen soft power seperti dikategorikan Daadaoui di atas sesungguhnya adalah manifestasi Khilafah yang khas Marokko, sehingga dapatlah dikatakan bahwa Khilafah merupakan pilar utama Makhzen. Daadaoui12 melihat, di dalam hubungan saling pengaruh antara hard power dengan soft power itulah terletak stabilitas dan daya tahan monarki Marokko. Demikian stabilnya kekuasaan monarki itu, bahkan ketika birokrasi pemerintahan tradisional diganti dengan birokrasi modern oleh penguasa Protektorat Perancis selama masa 1912-1956 M, upaya itu justeru menghasilkan perluasan batas Bled al-Makhzen atas Bled alSiba. Artinya, modernisasi birokrasi oleh penguasa pendudukan Perancis, malah mendorong perluasan wilayah yang langsung berada di bawah otoritas keagamaan monarki. Kondisi ini pada akhirnya, mewarnai dinamika politik pasca kemerdekaan $1956 \mathrm{M}$, yang menempatkan monarki Marokko dalam posisi hegemonik terhadap kekuatan politik lain, termasuk partaipartai politik. Dewasa ini supremasi Sultan Marokko relatif mutlak, karena berada di atas menteri-menteri dan bahkan melalui kekuasaan diskresinya, berada di atas parlemen.

Namun, pendudukan Perancis itu juga membawa konsekuensi lain. Dalam Perjanjian Fez 1912 M, yang menjadikan Marokko sebagai wilayah Protektorat Perancis disebutkan, bahwa baik otoritas keagamaan Sultan maupun kedaulatan sekulernya tetap dijamin, tetapi kekuasaan eksekutif dan militer berada di tangan Perancis. Dengan status sebagai wilayah Protektorat Perancis, Marokko tidak terbagi-bagi sesuai politik "pembagian Afrika" (the scramble for Africa) oleh para penjajah Eropa. Namun dengan status ini pula, arah masa depan Marokko ditentukan oleh Perancis, mengatasnamakan Sultan. Proses modernisasi oleh Perancis ditujukan untuk tidak mengakui eksistensi Marokko bersatu, tetapi memecah belahnya, terutama antara suku-suku Berber dengan Arab. Hal ini telah mendorong banyak kekuatan rakyat Marokko untuk bergerak membangun identitas nasional (nation-building).

Demikianlah, tidak ada ruang dan kekuatan yang cukup bagi Sultan Marokko untuk membangun "negara universal" seperti Khilafah di masa lalu. Semua negara teritorial (territorial nation-state) tetangga Marokko di Afrika, telah didefinisikan batas teritorialnya oleh para penjajah.13 Realitas politik ini memaksa Marokko merdeka pada 1956 M. bukan sebagai negara "Khilafah universal", melainkan "Khilafah teritorial".

Bagaimanapun, secara konseptual negara Makhzenit mencerminkan pola hubungan terirorial pusat dengan daerah dalam negara universal Khilafah di masa lalu. Batas-batas teritorial provinsi-provinsi perbatasan (frontier provinces) Khilafah dapat berubah secara dinamis, tergantung kemampuan kontrol pusat. Di provinsi-provinsi yang terjangkau kontrol pusat, dapat juga terjadi pembebasan diri dari penguasa pusat, atau perebutan kekuasan lokal yang mengubah status provinsi dari kontrol langsung pusat ke kontrol tidak langsung, menjadi sejenis wilayah vassal atau protektorat. Situasi dan kondisi ini menyediakan rujukan para ulama dalam menghasilkan rumusan teori Khilafah yang berbeda-beda.

\section{Pembahasan}

\subsection{Negara-Bangsa: Mesir dan Pakistan}

Meskipun negara Khilafah masih eksis hingga hari ini, narasi politik di dunia Islam lebih didominasi oleh pandangan bahwa Khilafah telah hilang pasca abolisi Kesultanan Turki 
Usmani. Narasi ini dapat dipahami terutama karena penghapusan Kesultanan dengan teritori dan pengaruh politik yang sangat luas, serta demikian perkasa selama lebih dari enam abad, merupakan kehilangan amat besar. Meski demikian, legitimasinya sebagai negara Khilafah tetap kontroversial. Sebagai kompensasi atas kehilangan ini, banyak pemikir muslim yang berupaya menemukan solusi alternatif, yang secara garis besar terbagi dua.

Solusi pertama, menghidupkan kembali model-model negara universal Khilafah atau yang sejenisnya seperti Pan-Islam. Solusi kedua, menerima realitas negara teritorial, yakni negara-bangsa dan gagasan nasionalismenya, serta merumuskan model-model adaptasinya. Kecuali Marokko yang mengalami transformasi dari negara "Khilafah universal" menjadi "Khilafah teritorial", bentuk solusi jenis pertama ada yang baru sebatas wacana saja, sebagaimana dirumuskan oleh Rasyid Ridla (w.1935 M.) di Mesir. Ada pula yang lebih konkrit berupa organisasi transnasional yang tidak berwujud negara seperti gerakan Hizb al Tahrir yang dirintis oleh Taqiyuddin al-Nabhani (w.1977 M.) di Palestina. Bentuk solusi lainnya adalah pendirian organisasi Islam internasional seperti Rabithah Alam Islami yang dipandang para ahli sebagai wujud Pan-Islam. Sedangkan solusi jenis kedua menemukan momentumnya ketika banyak wilayah hunian Muslim yang melepaskan diri dari penjajah Eropa memasuki abad ke-20 M. Bentuk pilihan empirisnya beragam, mulai dari penerapan Syari'at Islam secara langsung seperti Saudi Arabia; menjadikan Islam sebagai dasar negara seperti Mesir atau Pakistan; atau menempatkan Islam sebagai sumber moral seperti Indonesia. Di luar bentuk solusi yang mempertautkan agama dengan negara, banyak negarabangsa dengan penduduk mayoritas muslim yang memilih pemisahan lebih tegas di antara keduanya, seperti dilakukan Kemal Attaturk (w.1938 M.) di Turki.

Keragaman solusi di atas mencerminkan proses pencarian identitas dalam konteks hubungan antara Islam dengan negara yang masih berlangsung dalam realitas baru tatanan politik antar negara-bangsa. Kaum Muslim yang mendambakan solusi pertama dan menghadirkan kembali "negara universal" memiliki sandaran konseptualnya di masa lalu, yakni negara Khilafah. Sandaran konseptual ini masih terus mengalami eksplorasi oleh sekelompok kecil Muslim sebagai sumber ideologi Pan-Islam atau negara Khilafah. Namun bagi masyarakat Muslim yang mempertimbangkan tata dunia yang baru sebagai realitas, solusi kedua dipandang realistis meskipun memerlukan adaptasi konseptual yang berat, karena kebaruannya. Di sini, problem teroterialitas (territoriality) menjadi salah satu titik krusial yang memerlukan adaptasi. Banyak Muslim yang menolak gagasan nasionalisme dan menentang kehadiran negara-bangsa. Mereka memandang nasionalisme sebagai ideologi yang memecah belah dan melemahkan ummah menghadapi lawannya. Sebagaimana dikutipSami Zubaida,17 salah seorang pemikir Muslim modern, Sayid Qutub (1906-1966 M.) menjawab pertanyaan jaksa penuntut umum tentang patriotisme menyatakan:

Saya percaya bahwa ikatan ideologi dan iman lebih kokoh daripada ikatan patriotisme berdasarkan teritori dan bahwa perbedaan palsu di antara umat Islam berdasarkan teritori, tiada lain adalah konsekuensi dari perang salib dan imperialisme Zionis yang harus diberantas.

Lebih lajut, Qutub yang merupakan tokoh teras gerakan Al-Ikhwan al-Muslimun Mesir ini, juga menyatakan:

"Nasionalisme sekuler menciptakan perbedaan yang melahirkan kepahitan dan kebencian melalui perbedaan ras dan kebangsaan, di antara bangsa-bangsa. Negeri-negeri akhirnya berkelahi satu sama lain, daripada saling membantu."

Nasionalisme sekuler dipandang rasis dan regionalis yang harus ditolak. Nasionalisme semacam itu adalah berhala dan merupakan slogan jahiliyyah, yakni keadaan di mana Syari'at absen dalam mengatur kehidupan masyarakat, sebagaimana dulu di jaman praIslam. Menurut Qutub, Muslim tidak memiliki tanahair (homeland) selain dari (tanahair) yang 
menerapkan Syari'at. Muslim juga tidak memiliki nasionalitas (jinsiyyah) selain dari akidahnya sendiri yang menjadikannya anggota "ummah Islami" di tanahair Islami (dar alIslam). Ummah didefisinikannya secara harfiah sebagai "bangsa" (nation), sehingga para pengritiknya menyebut gagasan Qutub sebagai "Nasionalisme Islami" (al-qaumiyyah alIslamiyyah). Masyarakat bagi Qutub hanya ada dua, yaitu yang Islami berdasarkan Syari'at dan sebaliknya, yang jahili. Perubahan dari jahili ke Islami hanya dapat dilakukan dengan jihad, baik dalam arti dakwah dan atau perang fisik.

Qutub tidak berhasil merealisasikan gagasan "nasionalisme Islam" di Mesir. Bahkan, seruannya kepada para aktivis Muslim dalam bukunya Ma'alim fi al-Thariq (Suar Sepanjang Jalan) untuk menyiapkan revolusi mengakhiri Orde Jahili, diduga telah membawanya ke hukuman mati pada $1966 \mathrm{M}$. Teorinya tentang takfir (pernyataan bahwa pemerintah dan para pemimpinnya, serta seluruh masyarakat hingga ke tingkat tertentu adalah anti-Islam dan kafir) dalam buku itu, disepakati banyak ahli memberi inspirasi ideologis bagi gerakan seperti Al-Takfir wa al-Hijrah, dan kelompok radikal lainnya yang berhasil membunuh Presiden Anwar Sadat pada 1981 M.19 Pada akhirnya, pencarian identitas nasional Mesir tidak terlepas dari problem teritorialitas. Sejak lama, problem ini telah diupayakan diatasi oleh pemikir Rifa'at Rafi' AlTahtawi (w. 1873 M.).

Bagi Al-Tahtawi wathan (homeland, tanahair) menjadi arena pergumulan antara etika/hukum berbasis wahyu (Syari'at) dengan peraturan yang dihasilkan oleh akal/rasionalitas. Kewajiban utama individu Muslim kepada wathan adalah ishlah (perbaikan) dan perlakuan kepadanya ibarat kepada kedua orangtua yang menjadi tempat menemukan kebahagiaan bersama (fa-ka anna al-wathan huwa manzil aba'ihim wa ummahatihim wa mahall murabbahum fa-l-yakun mahallan li-sa'adatihim al-musyatarakah baynahum). Perbaikan wathan yang mengandalkan kombinasi antara etika/hukum wahyu dengan rasionalitas itu menghasilkan tamaddun (peradaban). Patriotisme bagi Muslim adalah mencintai agama dan mencintai wathan sebagai bagian dari keyakinan agamanya.

Gagasan Al-Tahtawi seperti diulas ringkas di atas itulah, yang tampaknya justeru berlangsung di Mesir dewasa ini. Upaya kombinasi antara etika/hukum wahyu dengan rasionalitas, terus dilakukan, meskipun mungkin tidak memuaskan banyak pihak. Konstitusi Mesir menyebutkan bahwa Islam adalah agama negara dan prinsip-prinsip Syari'at Islam adalah sumber utama hukum. Namun sistem hukum Mesir secara luas dibangun dengan mengacu kepada sistem Eropa, khususnya Perancis.

Akibatnya menurut Ali Agrama,banyak ketentuan mendasar Syari'at secara terangterangan terabaikan atau tidak diterapkan. Undang-undang yang mengatur keluarga disusun berdasarkan hukum agama, namun negara berupaya meliberalisasinya. Institusi-institusi keagamaan seperti Al-Azhar dan Dewan Fatwanya tetap hadir, namun dengan kewenangan terbatas dan secara resmi berada di bawah negara. Partai agama baik yang eksplisit maupun yang implisit mewakili gerakan keagamaan seperti Al-Ikhwan al-Muslimun, dilarang. Namun para anggota Ikhwan boleh menjadi anggota parlemen mewakili calon perseorangan. Meskipun konstitusi menjamin kebebasan beragama dan beribadah menurut agamanya, beberapa pengadilan membuat putusan melarang penggunaan jilbab di sejumlah sekolah dan profesi publik. Pemikiran Qutub banyak dipengaruhi oleh Abul A'la Maududi (1903-1979 M.) pemikir yang sebelum terjadi pemisahan Pakistan dari India pada 1947 M, adalah seorang idealis yang menjauhi politik dan menentang gagasan negara Pakistan.

Namun setelah Pakistan berdiri, Maududi pindah ke negara baru itu dan mendedikasikan sebagian besar hidupnya untuk dunia politik Pakistan. Dalam sejumlah tulisannya pada 1937 M, Maududi menyatakan bahwa dunia hanya mengenal dua sistem, yaitu Islam dan jahiliyyah. Dengan kehadiran Muhammad saw, sistem jahiliyyah dihapus dan diganti dengan sistem Islam sebagai agama wahyu yang universal, benar dan final. Hal ini 
berarti jenis budaya apapun berada dalam spektrum dua kutub: murni Islam (kebenaran mutlak, otentik) dan murni jahiliyyah (kepalsuan mutlak, tidak otentik).

Nasionalisme bagi Maududi lebih dekat ke kutub jahiliyyah. Bingkai jahiliyyah memudahkan Maududi menolak nasionalisme sebagai manifestasi modern bagi kejahilan praIslam daripada sebagai pencapaian kemajuan. Bagi Maududi, tanpa basis agama, capaian alamiah nasionalisme adalah persaingan antar bangsa-bangsa, antara lain karena kebanggaan dan pengagungan nasional. Semangat nasional adalah jahiliyyah dan secara umum, nasionalisme adalah sebentuk agama yang berkompetisi dengan ajaran wahyu para nabi.

Ketika Pakistan berdiri, fokus perjuangan Maududi beralih dari penolakan terhadap nasionalisme sekuler kepada transformasi negara-bangsa Pakistan sebagai negara (nasional) Islami yang sebenarnya, yang otentik. Tujuan peralihan itu adalah, memelihara identitas kolektif masyarakat Muslim menghadapi berbagai kekuatan politik, dalam proses ketatanegaraan (penyusunan konstitusi, legislasi, pemilu, kebijakan dalam negeri, kebijakan perang, dst.). Di sinilah, Maududi berkonsentrasi kepada gagasan politik tentang kedaulatan (sovereignty, hakimiyyah), yang kelak dianut juga oleh koleganya di Mesir, Sayid Qutub.

Bagi Maududi, kedaulatan itu mutlak harus diserahkan kepada Tuhan pembuat peraturan perundang-undangan. Penyerahan kedaulatan kepada pihak lain seperti rakyat dalam demokrasi, adalah tindakan menyekutukan Tuhan (syirk). Maka, Maududi mengajukan gagasan demokrasinya sendiri dalam negara (nasional) Islam yang disebut Theodemocracy,yaitu pemerintahan perwakilan yang dibatasi oleh hukum Islam.23 Bagi Maududi, karakteristik negara (nasional) Islam yang otentik mencakup: (1) kedaulatan hanya milik Tuhan; (2) hukum tertinggi adalah Syari'at; (3) pemerintah adalah pemegang amanah Tuhan dalam rangka melaksanakan kehendakNya; (4) pemerintah tidak boleh melampaui batas kewenangan yang telah ditetapkan Tuhan.

Dengan karakteristik negara (nasional) Islam seperti di atas, dapat diduga para ahli ilmu hukum Islam (ulama), melebihi segmen masyarakat Muslim lainnya, akan memiliki peran dan kewenangan sangat besar dalam proses penyusunan ketatanegaraannya. Tanzim Islam-I Pakistan, sebuah organisasi untuk reformasiPakistan menegaskan dalam petisinya kepada Pengadilan Tinggi Lahore pada 1976 M, bahwa dalam kerangka negara Islam, tidak ada ruang bagi penyusunan Undang-undang di luar interpretasi atas hukum Tuhan. Pembuatan hukum itu hanya boleh dilakukan melalui ijtihad (penetapan hukum Islam berbasis metodologi tertentu) oleh para ahlinya.

Seperti Qutub yang gagal di Mesir, Maududi juga tidak mampu mewujudkan pemikiran Theo-demokrasi di Pakistan. Realitas Pakistan pasca pemisahan dari India menyediakan banyak pilihan pemikiran politik yang saling berkompetisi sehingga tidak mungkin hanya mengandalkan satu pemikiran. Ali Jinnah (w.1948 M.) yang berasal dari minoritas Syi'ah Khojah dan pemimpin partai the Muslim League yang berkuasa, tidak mendukung gagasan sebuah bangsa Muslim, meskipun Pakistan dibangun dengan semangat Islam. Jinnah menghendaki suatu negara teritorial yang demokratis dan sekuler, menaungi semua komunitas keagamaan secara setara. Jenderal Ayub Khan (w. 1974 M.) yang pada 1958 M. mengkudeta presiden terpilih jenderal Iskander Mirza (w.1969 M.), menyukai sistem presidensial dengan pemilihan tidak langsung (perwakilan), karena dianggap lebih sejalan dengan konsep Khilafah.

Berikutnya, Zulfikar Ali Bhutto (w. 1979 M.) menginginkanSosialisme Islam berbasis tiga slogan: "Islam adalah agama kita; demokrasi adalah politik kita; Sosialisme adalah ekonomi kita". Jenderal Ziaul Haq (w.1988 M.) yang mengkudeta Ali Bhutto, memilih negara Islam berbasis Syari'at. Namun pada akhirnya, Pakistan tidak sepenuhnya menjadi negara Islam, tidak juga sepenuhnya menjadi negara demokratis.26 Louis Hayes27 mencatat, proses Islamisasi setelah Zia wafat terus melemah, meski tetap berlanjut. Bagi Hayes sendiri, 
Pakistan lebih cocok disebut "negara Praetorian", yakni negara yang masyarakatnya lebih banyak dipimpin oleh militer modern secara paksa.

\subsection{Negara-bangsa: Saudi Arabia dan Iran}

Saudi Arabia dan Iran menyumbang perbedaan pilihan identitas nasional kaum

Muslim. Konstitusi Saudi Arabia 1992 pasal 1 Dasar Negara menyatakan, Islam adalah agama Kerajaan; Al-Quran dan Sunnah Rasul saw adalah konstitusi Kerajaan. Pasal 23 menekankan, Negara harus melindungi dan menerapkan Syari'at Islam. Sedangkan pasal 55 menyatakan, Raja harus mematuhi Syaria't Islam dalam mengatur negara; Raja harus memastikan bahwa Syari'at Islam, hukum dan kebijakan umum Negara, serta perlindungan dan pertahanan Negara, dipatuhi.

Dalam praktik, kekuasaan negara dijalankan melalui kolaborasi dua kekuatan, yaitu ulama pengikut Syaihk Muhammad bin Abd al-Wahhab dan keluarga Saud selaku umara. Kolaborasi ini telah menjadi tradisi sejak awal abad ke-18, jauh sebelum Kerajaan Saudi Arabia dideklarasikan pada 1932 M. Menurut ulama Wahhabi terkemuka Abd al-Aziz bin Baz sebagaimana dikutip Al-Atawneh, kombinasi ulama/umara ini adalah ulu al-amr (pemilik otoritas) yang harus dipatuhi oleh kaum beriman, sebagaimana dimaksudkan dalam AlQuran surah An-Nisa (4):59. Tugas ulama adalah membuat interpretasi tentang keinginan Tuhan melalui analisis dan penafsiran atas firmanNya, sedangkan umara bertugas merealisasikan hasil-hasil interpretasi tersebut. Senafas dengan ayat di atas, bin Baz menyuruh kaum beriman untuk mena'ati pemerintah Saudi dan mengaitkankepatuhan kepada Allah dan Nabi-Nya dengan kepatuhan kepada penguasa duniawi itu. Kepatuhan ini akan membuka jalan bagi kebahagiaan di dunia dan di akhirat kelak.

Al-Atawneh30 melihat, pengaturan tugas ulama/umara yang bersifat kolaboratif di atas merupakan doktrin al-siyasah al-syar'iyyah, yang secara harfiah dapat diartikan sebagai "sistem politik Syari'at". Dalam tradisi mazhab Hanbali yang dekat dengan pandangan Wahhabi, doktrin itu lazim mencakup mekanisme maslahah (kepentingan), sehingga ulama Hanbaliah Ibnu 'Aqil merumuskan al-Siyasah al-Syar'iyyah dengan: "ma kana fi'lan yakunu ma'ahu al-nas aqrab ila al-maslaha wa ab'ad 'an al-fasad, wa in lam yasda'ahu al-rasul wa la nazala bihi wahi” (apa pun yang secara efektif menarik orang untuk lebih dekat kepada maslahah dan lebih jauh dari kerusakan, meskipun tidak berasal dari Rasul atau tidak turun dari Pemberi Wahyu). Bin Baz menggunakan prinsip maslahah 'ammah (kepentingan umun) sebagai acuan dalam kerangka alsiyasah al-syar'iyyah, agar tugas-tugas kolaboratif ulama/umara absah.

Bin Baz menganggap kepatuhan terhadap semua keputusan dan peraturan Kerajaan Saudi sebagai kewajiban, bahkan yang tidak tercakup dalam Syari'at, seperti peraturan lalu lintas, hubungan majikan-karyawan dan pengaturan sosial tertentu. Namun, ulama sebagai penjaga Syari'at, tidak hanya menyiapkan dan mengklarifikasi ajaran agama, tetapi mereka terlibat dalam pembuatan kebijakan sosial. Ulama Saudi hanya membisu dalam urusan politik praktis. Ulama dan umara menjadi institusi pembuat peraturan perundang-undangan dan karena itu, lembaga perwakilan dengan fungsi legislasi, tidak dikenal. \

Bahkan penggunaan istilah seperti qanun (hukum) dan musyarri' (legislator) terlarang, karena menyiratkan penerapan undang-undang gaya Barat. Iran pasca Revolusi 1979 M, menerapkan konsep Pemerintahan Islam (Syi'ah) berbasis Wilayat al-Faqih (Otoritas Ahli Fikih/Ulama), yang diteorisasikan oleh Ayatullah Ruhullah Khomeini (w.1989 M.) dan tertuang dalam Konstitusi 1979 M. Struktur kekuasaan puncak di Republik Islam Iran berada di tangan seorang Pemimpin Tertinggi (the Supreme Leader, Rahbar Mo'azzam) yang bertugas seumur hidup. Rahbar Mo'azzam harus memenuhi sejumlah persyaratan, di antaranya seseorang yang diterima oleh mayoritas rakyat sebagai pemimpin (Rahbar), 
sekaligus Ayatullah ahli hukum Islam dengan derajat Marja' Taqlid (Rujukan Taklid). Contohnya adalah Imam Khomeini sendiri. Atau, untuk selain Khomeini, Majelis Pakar (Asembly of Experts, Majles-e Khobregan) yang dipilih rakyat, mempertimbangkan semua orang yang memiliki kualifikasi ganda sebagai Rahbar dan Marja'. Jika Majelis Pakar menemukan orang seperti itu, maka yang bersangkutan diumumkan sebagai RahbarMo'azzam. Jika tidak, maka ditetapkan tiga atau lima Marja' yang memiliki kualifikasi kepemimpinan dan mereka diumumkan kepada rakyat sebagai para anggota Majelis Pimpinan (Leadership Council).

Majelis Pakar terdiri atas delapanpuluh enam orang ahli hukum Islam, yang dipilih untuk masa tugas delapan tahun, melalui pemilu di tigapuluh daerah pemilihan seluruh Iran. Tugas utama Majelis ini adalah memilih Pemimpin Tertinggi (Rahbar Mo'azzam) dan melakukan monitoring atas pelaksanaan tugasnya. Fungsi kedua itu hingga kini tidak efektif karena sejumlah sebab, di antaranya ketiadaan mekanisme monitoring dan standar kinerja lainnya. Lima anggota Majelis ini menjadi anggota Dewan Pengawal (Council of Guardians, Shura-ye Negahban) yang lebih fungsional dari Majelis. Dewan ini beranggota duabelas orang, enam di antaranya ahli Fikih yang ditunjuk langsung oleh Rahbar Mo'azzam. Enam lainnya ialah ahli hukum umum yang ditetapkan Parlemen atas rekomendasi Ketua Badan Peradilan (Head of Judiciary, yang diangkat oleh Rahbar Mo'azzam). Tugas Dewan ini adalah menjamin seluruh legislasi di Parlemen sejalan dengan Syari'at Islam. Dewan juga bertanggungjawab atas pelaksanaan dan pengawasan pemilu anggota Majelis Pakar, Presiden dan anggota Parlemen, serta jajak pendapat umum dan referendum. Dalam tugas ini tercakup penyaringan kualifikasi dan konfirmasi para calon pengisi jabatan publik itu.

Dengan kewenangan mengangkat panglima tentara dan menempatkan wakilnya di semua institusi negara dan lembaga keagamaan, maka otoritas Rahbar Mo'azzam jelas absolut. Pada 1985 M, Majelis Pakar menetapkan Grand Ayatullah Ali Montazeri sebagai penerus Khomeini. Montazeri memenuhi kualifikasi ganda sebagai Rahbar dan Marja'. Meskipun menerima konsep Wilayah al-Faqih, Montazeri menolak posisi Rahbar Mo'azzam yang berkuasa mutlak dan penempatannya di atas hukum. Bagi Montazeri, Pemimpin Tertinggi itu harus tunduk kepada Konstitusi dan kehendak rakyat.

Kritiknya semakin keras sesudah eksekusi Mehdi Hashemi pada 1987 M, dan eksekusi massal ribuan tahanan politik pada 1988 M. Hashemi, tokoh Garda Revolusi (Pasdaran) yang loyal kepada Montazeri, dihukum mati menyusul kebocoran informasi transaksi senjata antara Iran dengan Amerika Serikat dan Israel. Pada 1989 M, Imam Khomeini memecat Montazeri dan mengubah Konstitusi, sehingga memungkinkan seorang non-Marja' menjadi Rahbar Mo'azzam dan menghapus kemungkinan posisi itu dipilih melalui pemilu. Perubahan ini melapangkan jalan bagi Ali Khamene'i mengganti Khomeini meraih posisi Rahbar Mo'azzam, meski levelkeagamaannya saat itu baru Hojjatol Eslam, belum Ayatullah atau Grand Ayatullah/Marja'.3

\subsection{Indonesia}

Dalam dua dekade menjelang Indonesia merdeka, pergulatan pemikiran tentang masa depan wilayah jajahan Hindia Belanda diwarnai oleh ketegangan antara gagasan pembentukan negara universal Khilafah dengan negara-bangsa teritorial. Namun, gagasan negara Khilafah menghilang setelah para pendukungnya dari Partai Sarekat Islam (SI) mengalihkan perhatian mereka kepada posisi Islam dalam kerangka negara-bangsa. Para tokoh SI seperti Agus Salim (w.1954 M.), terlibat perdebatan dengan para pemikir lain, khususnya Sukarno (w.1970 M.), tentang negara-bangsa: Apakah agama (Islam) harus menyatu dengan negara, atau terpisah? Perdebatan sengit menyangkut soal krusial ini terus berlangsung selama proses-proses perumusan Konstitusi bagi negara-bangsa yang baru, 
Indonesia. Pada akhirnya, trauma penjajahan yang panjang telah mendorong para pemikir kebangsaan menemukan titik temu, yakni Pancasila sebagai dasar Negara Republik Indonesia dan Undang-undang Dasar 1945 sebagai Konstitusinya.

Sesudah proklamasi kemerdekaan pada 1945 M, upaya untuk mengubah Pancasila dan UUD 1945 serta mendirikan negara (nasional) Islam tetap dilakukan oleh segmen tertentu Muslim Indonesia. Penolakan melalui jalan militer dilakukan misalnya oleh gerakan Darul Islam (1950-1962 M.) pimpinan Kartosuwiryo (w.1962 M.). Sedangkan perubahan melalui jalan politik, diupayakan antara lain dalam Dewan Konstituante hasil pemilu 1955 M. Upaya ini gagal dan melahirkan Dekrit Presiden 1955 M, yang mengembalikan posisi semula Pancasila dan UUD 1945. Sejak Dekrit ini, penerapan Pancasila dan UUD 1945 telah menghasilkan empatpuluh tahun pemerintahan otoriter, hingga muncul gerakan Reformasi 1998 M, menuntut demokratisasi dan amandemen Konstitusi. Empat kali amandemen UUD 1945 antara 1998-2002 M, memberi peluang gagasan Syari'at Islam secara formal masuk kembali dalam Konstitusi. Upaya kedua ini juga gagal, karena banyak faktor. Bagaimanapun, Reformasi membuahkan keterbukaan bagi aspirasi politik berbasis agama. Kini, partai politik misalnya, dapat menggunakan Islam sebagai landasan perjuangannya.

\section{Kesimpulan}

Bagi pemikir Nurcholis Madjid (Cak Nur),37 Pancasila adalah final dalam fungsinya sebagai landasan kehidupan bermasyarakat dan bernegara di Indonesia yang majemuk. Pancasila juga final dalam hal rumusan kalimatnya yang formal sebagaimana tertera dalam Pembukaan UUD 1945. Cak Nur melihat masih banyak pihak yang enggan menerima kefinalan Pancasila karena khawatir Pancasila akan diarahkan menyaingi atau mengganti suatu agama. Pancasila, dari sejumlah fungsi dan dan kedudukannya, harus dipandang sebagai titik temu (kalimatun sawa) di antara berbagai komunitas kemasyarakatan, khususnya komunitas keagamaan. Bagi Cak Nur, Al-Quran surah Ali Imran: 46 mengandung perintah untuk mencari titik temu antara para penganut agama, yaitu Tauhid, atau paham Ketuhanan Yang Maha Esa (Monoteisme). Konsekuensi Tauhid adalah tidak ada pemitosan sesama manusia atau sesama makhluk. Ketika titik temu yang paling pokok telah disepakati, lalu titik temu selanjutnya yang dipandang baik oleh semua dapat pula disetujui, maka hal itu menjadi keutamaan. Menurut Cak Nur, langkah seperti itu sejalan dengan prinsip ushul alfiqh (legal maxims) yang berbunyi: ma kana aktsara fi'lan, kana aktsara fadl lan (Sesuatu perbuatan baik-- yang semakin banyak dikerjakan, maka semakin banyak keutamaannya). Pancasila sebagai titik temu hasil kesepakatan, harus dibiarkan sebagai nilai-nilai dasar yang terbuka dan tidak menyediakan penafsiran detail indoktrinatif. Setiap rincian konseptual atas nilai-nilai dasar itu harus diuji di hadapan realitas masyarakat yang terus berubah, sehingga tidak ada detail "sekali untuk selamanya" yang tabu bagi perubahan. Singkatnya, Islam telah dan dapat menjadi sumber substansial bagi ideologi dan etos nasional.

Pilihan-pilihan adaptasi penerapan ajaran Islam oleh kaum Muslim menghadapi realitas negara-bangsa sebagaimana tampak dalam enam contoh di atas, secara konseptual memerlukan kerangka baru. Kecuali Marokko yang menampilkan transformasi negara

Khilafah, serta Saudi Arabia yang dapat diletakkan dalam kerangka konseptual al-Siyasah alSyar'iyyah, meskipun dari sisi pembentukan negara dapat disebut bercorak Khaldunian,38 empat contoh lainnya belum memiliki rujukan "kerangka ide" (ideal type) dalam sejarah kaum Muslim. Keempatnya dapat ditempatkan dalam ruang perdebatan antara dua pendekatan dalam politik Islam (Islamic polity), yaitu pendekatan institusional dan pendekatan substantif.39 Pendekatan pertama menekankan kebutuhan atas institusi negara dalam pelaksanaan ajaran Islam, seperti perubahan konstitusi dan sistem hukum nasional dari 
wajahnya yang "sekuler" menjadi "Islami", serta penegakan hukum Islam secara koersif. Sedangkan pendekatan kedua lebih menekankan substansi daripada bentuk dan fokus kepada tujuan-tujuan yang ingin dicapai negara nasional seperti keadilan sosial, hak asasi manusia, atau penegakan hukum, yang sejalan dengan substansi Islam. Baik pendekatan pertama maupun kedua, belum ditemukan preseden konseptualnya di masa lalu. Dalam konteks inilah, konsep al-Siyasah al-'Aqliyyah sebagaimana dirumuskan Ibnu Khaldun (w.1406 M.), memiliki relevansi.

\section{Daftar Pustaka}

Jamil M. Abun-Nasr (1987): A History of the Maghrib in Period, the Islamic Cambridge, Cambridge University Press, hlm.206-227; Nehemia Levtzion (1975) :"North-West Africa: from the Maghrib to the Fringes of the Forest" dalam Richard Gray (ed): The Cambridge History of Africa Vol.4 (1600-1790), Cambridge, Cambridge University Press, hlm. 145-158.

Sebagaimana dikutip oleh Abdul Aziz (2019): Kontroversi Khilafah, Yogyakarta, LKIS, hlm.69.

Stephen Cory (2010): "Sharifian Rule in Morocco (Tenth-Twelfth/Sixteenth-Eighteenth Centuries)", dalam Maribel Fierro (ed.):The New Cambridge History of Islam, Volume.2, The Western Islamic World Eleventh to Eighteenth Centuries, Cambridge, Cambridge University Press, hlm.454-455.

Jamil M. Abun-Nasr (1987): A History of the Maghrib, Op.Cit, hlm.206, 211.

Stephen Cory (2010): "Sharifian Rule..." dalam Ibid, hlm.457.

Lihat Amira K. Bennison (2002): Jihad and its Interpretation in Pre-colonial Morocco, London, Routledge, hlm.19-24. Istilah "Syarifisme" (Sharifism) diadaptasi dari Bennison. Istilah lain yang maknanya sama adalah Syarifianisme (Sharifianism), dapat dilihat dalam Jonathan Wyrtzen (2018): "The Commander of the Faithful and Moroccan Secularity" dalam M.Künkler; J. Madeley; S.Shankar (eds.): A Secular Age Beyond the West (Religion, Law and the State in Asia, the Middle East and North Africa), Cambridge, Cambridge University Press, hlm.317-341. Tentang institusi Makhzen, lihat Mohamed Daadaoui (2011): Moroccan Monarchy and the Islamist Challenge, Maintaining Makhzen Power, New York, Palgrave Macmillan, hlm.42.

Jamil M. Abun-Nasr (1987): A History of the Maghrib, Op.Cit, hlm.228-243.

Untuk peran Isma'il dan Muhammad III lihat Mohamed Daadaoui (2011): Moroccan Monarchy, Op.Cit, hlm.45.

Nehemia Levtzion (1975) :"North-West Africa..." Op.cit, hlm.147.

Meryem Akabouch (2014): Islam, National Identity and Social Cohesion, The Case of Morocco, Disertasi Doktoral Tidak Diterbitkan, Libera Universita Internazionale degri Studi Sociali (LUISS), Roma, hlm.30-35.

Mohamed Daadaoui (2011): Moroccan Monarchy, Op.Cit, hlm.45-53.

Mohamed Daadaoui (2011): Moroccan Monarchy, Ibid, hlm. 54-62

Jonathan Wyrtzen (2009): Constructing Morocco: The Colonial Struggle to Define the Nation, 1912-1956, Disertasi Doktoral Tidak Diterbitkan, Georgetown University, Washington DC, hlm.39-45; 135-159; Tentang pembagian Afrika oleh penjajah lihat Barbara Harlow and Mia Carter (2004): Archives of Empire, Volume 2: The Scramble for Africa, Durham, Duke University Press, hlm.17-18. Istilah territorial nation-state dipinjam dari Sami Zubaida (2004): "Islam and Nationalism: Continuities and Contradictions" dalam Nations and Nationalism Vol.10, No.4, hlm. 407-420. 
Abdul Aziz (2019): Kontroversi Khilafah, Op.Cit, hlm.17-19. Potret hubungan pusatprovinsi di negara Khilafah dapat dilihat dalam Hugh Kennedy (1981): " Central Government and Provincial Élites in The Early 'Abbāsid Caliphate" dalam Bulletin of the School of Oriental and African Studies, Vol. 44, No.01, hlm.26-38.

Abdul Aziz (2019): Kontroversi Khilafah, Op.Cit, hlm. 145-148. Diskusi tentang dua alternatif ini lihat Abdul Aziz (2016): Chiefdom Madinah, Kerucut Kekuasaan Pada Zaman Awal Islam, Jakarta, Alvabet, hlm.91-109.

Lihat Abdul Aziz (2018): Islam Vesrus Demokrasi, Menguak Mitos, Menemukan Solusi, Yogyakarta, LKIS, hlm.234-244

Sami Zubaida (2004): "Islam and Nationalism...", Op.Cit, hlm.407. Pernyataan Qutub diterjemahkan dengan adaptasi.

Lihat Sayed Khatab (2004):"Arabism and Islamism in Sayyid Qutb's Thought on Nationalism" dalam The Muslim World, Vol. 94, No.2, hlm. 217-244, kutipan diterjemahkan dengan adaptasi; Wlliam E. Shepard (2020): "Qutb, Sayyid" dalam James Fieser and Bradley Dowden (eds.) The Internet Encyclopedia of Philosophy, ISSN 2161-0002, https://www.iep.utm.edu/ diakses 29 Januari 2020.

William E. Shepard (1992). The Development of the Thought of Sayyid Qutb as Reflected in Earlier and Later Editions of 'Social Justice in Islam.' Die Welt Des Islams, Vol. 32, No.2), hlm. 196-236. Menurut Saad Eddin Ibrahim gerakan dan kelompok radikal Mesir dipengaruhi oleh banyak pemikiran selain Qutub, seperti Hasan Al-Banna, Abul A'la Maududi dan lebih jauh lagi Ibnu Taimiyah. Lihat Saad Eddin Ibrahim: "Anatomy of Egypt's Militant Islamic Groups; Methodological Note and Preliminary Findings" dalam International Journal of Middle East Studies, Vol. 12, No. 4 (Dec., 1980), pp. 423-453.

Sebagaimana dikutip oleh Mohammad Fadel (2012): "Modernist Islamic Political Thought and the Tunisian and Egyptian Reolution of 2011" , Legal Philosophy between State and Transnationalism Seminar Series 10, York University, 3-2-2012, hlm.8-24.

Hussein Ali Agrama (2012): Questioning Secularism. Islam, Sovereignty and the Rule of Law in Modern Egypt, Chicago, The University of Chicago Press, hlm.1-3

Mohammad Adnan Rehman (2018):"Nation as a Neo-Idol: Muslim Political Theology and the Critique of Secular Nationalism in Modern South Asia" dalam Religion Vol.9, No.355, hlm. 1-26

Dikutip dari Mohammad Adnan Rehman (2018):" Nation as a Neo-Idol..." Ibid, hlm.17-18.

Dikutip dari Abdul Aziz (2016): Chiefdom Madinah, Op.Cit, hlm. 131.

Dikutip dari Ishtiaq Ahmed (1991): The Concept of an Islamic state in Pakistan, an Analysis of Ideological Controversies, Lahore, Vanguard Books, hlm.90.

Ishtiaq Ahmed (1991): The Concept, Ibid, hlm. 15-18;27-28;78-79.

Louis D. Hayes (2014): The Islamic State in the Post-Modern World, The Political Experience of Pakistan, Farnham Surrey, Ashgate Publishing, hlm.109-118.

Saudi Arabia: "The New Constitution, The Kingdom of Saudi Arabia 1993", dikutip dari Arab Law Quarterly volume 8, issue 3 (1993)

Sebagaimana dikutip oleh Muhammad Al-Atawneh (2017): "Authority-Holders (wulat alumur) in Contemporary Islamic Politics and Governance: The Case of Saudi Arabia", dalam Middle East Critique, Vol.26, No.2, hlm.123-136.

Muhammad Al Atawneh (2017): "Authority-Holders..." dalam Ibid, hlm. 128-13

Lihat juga catatan kaki no.32 tentang sejumlah definisi al-Siyasah al-Syar'iyyah. Joseph Nevo (1998): "Religion and National Identity in Saudi Arabia" dalam Middle Eastern Studies, Vol. 34, No. 3, hlm.35. 
Wilfried Buchta (2000): Who Rules Iran. The Structure of Power in the Islamic Republic, Washington DC, The Washington Institute for Near East Policy and the Konrad Adenauer Stiftung, hlm. 46-55; Firoozeh PapanMatin (trans.) (2014): "The Constitution of the Islamic Republic of Iran (1989 Edition)", dalam Iranian Studies, Vol.47, No.1, hlm. 184 dan Catatan Kaki No.16.

Wilfried Buchta (2000): Who Rules Iran, Op.Cit, hlm.58-60; Farshad Malek-Ahmadi (2015): Democracy and Constitutional Politics in Iran, A Weberian Analysis, New York, -Palgrave Macmillan, hlm.64-83.

Wilfried Buchta (2000): Who Rules Iran, Op.Cit, hlm.52-54; Hamid Mavani (2013): “ Khomeini's Concept of Governance of the Jurisconsult (Wilayat al-Faqih) Revisited: The Aftermath of Iran's 2009 Presidential Election”, dalam The Middle East Journal, Vol.67, No.2, hlm. 207-228.

Untuk perdebatan dan diskusi lihat Abdul Aziz (2016): Chiefdom Madinah, Op.Cit, hlm.110-120; Yudi Latif (2011): Negara Paripurna, Historisitas, Rasionalitas dan Aktualitas Pancasila, Jakarta, Gramedia, hlm.9-40.

Tentang Darul Islam lihat Chiara Formichi (2015): “(Re) Writing the History of Political Islam in Indonesia", dalam Sojourn, Journal of Social Issues in Southeast Asia, Vol.30, No.1, hlm.105-14. Tentang upaya politik, lihat R.E. Elson (2013): "Two Failed Attemp to Islamize the Indonesian Constitution", dalam Sojourn, Journal of Social Issues in Southeast Asia, Vol. 28, No. 3, hlm. 379-437.

Nurcholis Madjid (2007): "Islam di Indonesia dan Potensinya Sebagai Sumber Substansiasi Ideologi dan Etos Nasional" dalam Nurcholis Madjid, Dkk: Islam Universal, Yogyakarta, Pustaka Pelajar, hlm.166-184.

Rujuk teori lima mata rantai siklus pembentukan negara dari Ibnu Khaldun sebagaimana dijelaskan dalam Syed Farid Alatas (2014): Applying Ibn Khaldūn The Recovery of a Lost Tradition in Sociology, London, Routledge, hlm.132-137.

Dua pendekatan ini dan penjelasannya dipinjam dari Wahabuddin Raees (2013): "Building Islamic Polity Within a Secular Framework of Political Activity in Egypt, Tunisia and Turkey, with Reference to Ibn Khaldun's Theory of State" dalam Al-Shajarah Journal of ISTAC-IIUM, Vol.18, No.1, hlm. 60-62. 